University of Louisville

ThinkIR: The University of Louisville's Institutional Repository

Electronic Theses and Dissertations

6-1947

\title{
A substitute for wood veneer.
}

Edwin R. Arbegust

University of Louisville

Follow this and additional works at: https://ir.library.louisville.edu/etd

Part of the Chemical Engineering Commons

\section{Recommended Citation}

Arbegust, Edwin R., "A substitute for wood veneer." (1947). Electronic Theses and Dissertations. Paper 1858.

https://doi.org/10.18297/etd/1858

This Master's Thesis is brought to you for free and open access by ThinkIR: The University of Louisville's Institutional Repository. It has been accepted for inclusion in Electronic Theses and Dissertations by an authorized administrator of ThinkIR: The University of Louisville's Institutional Repository. This title appears here courtesy of the author, who has retained all other copyrights. For more information, please contact thinkir@louisville.edu. 
UNIVERSITY OF LOUISVILLE

A SUBSTITUTE FOR WOOD VENEER

\author{
A Thesis \\ Submitted to the Faculty \\ of the Graduate School \\ of the University of Loulsvilie \\ in Partial Fulfillment \\ of the Requirementa \\ for the Degree of \\ MASTER OF CHEMICAL ENGINEERING \\ Department of Chemical Engineering
}

Edwin R. Arbegust

June 1947 
A SUBSTITUTE FOR WOOD VENEER

Edwin R. Arbegust

Approved by the Examining Committee. Director

June 1947 
TABLE OF CONTENTS

Page

List of Tables . . . . . . . . . . . . iv Acknowledgment . . . . . . . . . . . . v v Abstract . . . . . . . . . . . . . . v1 Introduction .................... I H1stortcal ............... 4 Theoretical .................. . 10 Experimental Procedure and Regults . . . . . . . 14 Summary and Conclusions ........... 53 Literature cited . . . . . . . . . . . 55 Acknowledgment . . . . . . . . . . . 58 V1ta . . . . . . . . . . . . . . 59 


\section{LIST OF TABLES}

I Comparison of Tensile and Flexure strengths of Glyoxal-starch, Glyoxal-starch-silicate, and Starch-silicate F1berboard........... 33

II Comparison of Wet and Dry Strengths of the Glyoxal Type Fiberboard . . . . . . . . . 35

III Comparison of Dry Tension Tests of Fiberboard with Corrugated Paperboard and Wood Veneer . . . 44

IV Comparison of Dry Tensile Strengths of Fiberboard with Corrugated Paperboard and Wood Veneer .. . . . . . . . . . . . 46

$\checkmark$ Comparison of Flexure Tests of Corrugated Paperboard, Wood Veneer, and Fiberboard . . . 47

VI Comparison of Impact Tests of Wood Veneer with F1berboard ... . . . . . . . . . 48

VII Comparison of Dry and Wet Tensile Strengths of Different Types of Fiberboard... . . . . . 50 
Acknowledgment

The author wishes to acknowledge

the kind assistance and helpful guidance

of Dr. G. C. W1Iliams

who directed this research 
Abstract

Th1s thesis is a report of an investigation for a substitute for wood veneer to be used as face matertal for wire-bound boxes. The fiberboard substitute was made using a heavy paper backing with a wood waste mixture of chips and aawdust with various types of adhesive binders. The following adhesives were used singly and in mixtures: Starch, sodium silicate, asphalt emulsion, animal glue, urea resin with a wheat flour extender, rosin, and casein. The composition and test results of the fiberboard panels made in the laboratory are reported. 
INTRODUCTION 
In the packaging industry there are many and varied forms of containerg which are chosen for characteristics peculiar to their structure and necessary for their use. In this field there is one type of container which is known as the wire-bound box.

The wire-bound box industry uses rotary cut, sliced veneer, or thin sawed lumber in combination with wood cleats, wires, and staples to produce wire-bound boxes with the veneer being used as a face material. Shortly after the war began in 1942, wood veneer became one of the scarce commodities. This shortage of veneer seemed to grow worse, and if this condition continued, the production of wire-bound boxes would be curtalled. An investigation is reported in this thesis for a substitute for wood veneer to be used as face material for wire-bound boxes, and was a portion of contracted research in the University of Loulaville Institute of Industrial Research.

There are many types of fiberboard produced commercially at the present time with the use of diverse materiala. These include extracted sugar cane (bagasse), sawn1ll waste, straw, comstalks, srasses, extracted roots, tobacco stems, waste paper, bark, and severel other types of flbers obtalned from asricultural wastes and byproducts. However, the most common fiberboard is made with chemically or mechanically processed wood pulp on a modified paper machine of the mult1cylinder type. This machine can make a fiberboard of one mat 
or several mats bound together with an adhesive in much the same manner that plywood is made. One of the main disadvantages of these flberboards is the low water resistance. This falling is somewhat alleviated by the addition of rosin sizing, waxes, gums, pitch, or emulgified asphalt.

The wood veneer now used as face material costs about one and a half cents per square foot. The veneer substitute should cost no more than this amount if possible and this value is low enough to mile out almost all materials but wastes of some type. In the sawing and planing operations of the wood container and other wood working plants, the largest waste on a weight basis is that in the form of chips and sawdust. Therefore, it was proposed to use this waste as a major raw material for the veneer substitute. It was also proposed to use a heavy paper backing, such as 0.030 jute, with this wood waste. This necessitates the use of a low price adhestve binder as the cost margin 18 very small. The paper backing would also simplify the commercial production of a board, since 1t would act as a carrier while the board was being fabrtcated. An all weather board could be made by this method by using a water repellent backing. The use of paper backing would also permit the finished product to have any desired appearance; printed material could be put on the outer surface in the same manner that is used in the paperboard Industry • 
HISTORICAL 
Many types of fiberboard have been made for constmuction and insulation purposes. (1-8). One type was used as a wallboard of commercial importance about 1906 (9). Although many kinds of flbers obtained from agricultural wastes have been used, the most common fiberboard is made with chem1cally or mechanically processed wood pulp (9-13). One type of fiberboard that is produced from wood fiber on a large scale 1s Masonite (14, 15). In the Masonite process wood chips are treated with high pressure steam for several minutes; the pressure is then suddenly released by blowing the material through a specially designed nozzle. This action reduces the chips to minute fibers which are subsequently compressed at a temperature of $350^{\circ} \mathrm{F}$. This process gives an extremely hard, strong fiberboard which is sidely used in constmuction work for 1ts atrength and attractiveness (16, 17).

During the war, the V-type fiberboard was developed by the container industry (18-21). This was used for contalners for overseas shipment. The two important characteristics of this board were its strength and moisture resistance. This board was made of wood pulp to which had been added an adhesive. The adhesives were of polyvinyl melamine, or urea resin types with extenders of starch or emulsified asphalt. The biggest disadvantage of this board was its high cost.

Another type of flberboard that is well known in this country is celotex (22). After the first world war, a systematic evaluation of various fibers for the manufacture of 
fiberboard was undertaken. After considering the technical and economical factors involved, begasse, the waste material of the sugar industry was found the most suitable for this purpose. The sugar industry in the southerm part of the United States had thousands of tons of bagasse as waste material. The disposal of this waste was a sertous problem because of the large quantities involved. If it were left in the flelas it would considerably reduce the avallable acreage for ralsing sugar cane. These flbers were almost totally resistant to weathering. In 1922 eighteen million square feet of Celotex was produced; by 1930 the production of this board had reached flve hundred million square feet. At the present time bagasse furnishes the sugar producers a considerable part of their total income. Many of the problems of manufacturing the bagasse board re-occurs in making fiberboard from wood wastes, therefore, some manufacturing detalls of celotex will be discussed. The large degree of production control results in ten per cent of the personnel employed being coneerned with control work. However, the largest part of the manufacturing cost occurred in drying the board to the proper molsture content. This board was dried using steam at $175 \mathrm{pg}$ and $1000 \mathrm{~F}$ superheat in a drier 800 feet long. The resulting board from the drier was practically bone dry. It was then sprayed with clean water to allow it to come to its equilibrium molsture content. This prevented the board from warping. Two types of fiberboard made in Germany during the 
war were Tronal and Dynal. A complete discussion of these types of fiberboard is given in a report by N. B. Hutcheon of the University of Saskatchewan (23). This is a report of his interview with Dr. Barchfield at Dynamit $A$. G. at Trolsdorf, Germany. Dr. Barchfield discovered that wood f1ber made from chips or sawdust in a Hollander, a pulp grinding machine, could be used to make fiberboard. This pulp was made into a board much the same way as is done in Canada and the United states. The pulp is poured into trays in which water is removed by means of a screen bottom. It was found that waste from rope factorles, stalks from rope, hops, heather and straw could be treated this way. In addition, he also discovered that this pulp prepared in a Hollander could be used as a binder for coarser materials, such as chlps or sawdust, and then pressed into a board. The binding properties of this pulp was due to the formation of a gelatinous material which could be produced in any desired proportion by varying the time of grinding.

Tronal was produced at a cost of about one mark per square meter, which is slightly more than one cent per square foot. It was discovered by accident that Tronal could be made water repellent by heating it after manufacture to just below the charring point, about 3900F. Boards made this way could be immersed for 72 hours in water with a rise in molsture content to no more than $15 \%$. Tronal was used for some phases of alrcraft production. An experimental house was also made of this material. Dynal was made by dipping paper in phenolin 
resin and then bonding under heat and pressure as many of these paper layers to give a board of desired thlckness. Dynal was also used for aircraft construction. Battery boxes used in submarines were made from Dynal but the production cost was high.

In order to set the requirements for the f1berboard to be made, a consideration of the manufacture and use of wire-bound boxes is necessary. This information was taken from an article by J.A. Deluca (24) and also from the report of the tests made on wirebound boxes made from fiberboard at the Package Research Laboratory, Rockaway, New Jersey (25). In the Transactions of the A.S.M.E., February, 1947 J. A. Deluca has written a summary of the construction and use of wire-bound boxes. The wire-bound box is a lightweight type of shlpping container that utilizes rotary-cut lumber, sliced lumber, or thin sawed lumber in combination with cleats, wires, and staples. Wire-bound boxes differ from nalled boxes in that the sides and ends of the wire-bound boxes are usually of the same thickness. The thin material in the ends, sides, top, and bottom springs and thus absorbs the shocks that would otherwise be transmitted to the commodity. This springing action enables the wire-bound box to withstand rough handing. The material used, usually veneer, must be resilient. Wirebound boxes are made by stapling two or more wires spaced a determined distance apart by special machines to the side, bottom, side, and top box parts, consectuvely, to form a mat. 
The end staples on each part span the binding wires and pass through the board material and into the end cleats. The staples over the intermediate binding wires are clinched on the Inner surface of the board material. Fallurea in wire-bound boxes usually occur at or near the jolnts between the end cleats and the sides, top and bottom, although occasional failures are caused by the binding wires breaking or the sides, top and bottom puncturing or breaking the wires. Mr. Henry A. Wolsdorf, Vice-President of the Stapling Machine Company gave the requirements of face material for wire-bound boxes as (25):

1. Light in weight

2. Reasonably high tensile and flexure strengths

3. Resilient

4. Hard enough to resist cutting by the staples or wires under rather severe conditions.

The face material must be light in weight, otherwise the shlpping costs would be unduly high. Items \#2 and \#4 are important because of the severe conditions the boxes are required to undergo. The property of resilience allows the face panels to absorb the shock of rough handing that would ordinarliy be transmitted to the contents. They should also be reasonably water resistant and repellent. 
THEORETICAL 
The Theory that is involved in the manufacture of this type of f1berboard can be divided into two parts; first, the action of the adhesive, and secondly, the chemical and physical action of the mass while the adhesive sets or cures. Adhesives can be classified by the way they set, either thermoplastic or thermosetting. The most widely used commercial adhesives are the thermosetting type. On the application of heat and pressure the adhesive softens and then hardens irreversibly; it is not again softened by further heating. The urea type resins polymerize with formaldehyde to give this kind of an adhesive (26) as also do the phenol group.

Two types of adhesion are known, mechanical adhesion and specific adhesion. Mechanical adhesion attributes the adhesiveness of the glue to wood to the following action: The glue, while fluid, penetrates into the cavities in the wood structure and then solidifies. Thus the strength of the joint is credited to the interlocking of the two solids, wood and glue. Since it is a well known fact that smooth surfaces such as metal, plastics and glass can be successfully glued together, mechanical adheston does not completely explain the nature of adhesion. This other type of adhesion involved is known as specific adhesion and is attributed to the electric properties of the adhesive and adhered surfaces ( 27 ). In 1939, N. A. de Bruyne, oB Aero Research, Ltd., Englend, published a report concerning the nature of specific 
adhesion(28). Although the atoms and molecules of any substance are electrically neutral, it is a well established fact that secondary forces exist between them. These secondary forces are of two definite types, polar and nonpolar. Wood, in its normal state is non-polar. De Bruyne has furnished evidence to show that in using pure or simple substances as adhesives "strong joints can not be made to polar adherents with non-polar adhesives, nor to non-polar adherents with polar adhesives."

Many other investigators have studied the nature of adhesion between glue and wood. Probably the most complete and accurate discussion is found in the report by Browne and Brouse, the "Nature of Adhesion between GIue and Wood". This publication shows the weakness of the old hypothesis concerning the neture of adhesion. This hypothesis states a comparison of the strength of wood joints in shear and tension with the strength of flims of "strong" and "weak" glues in tension indicates that glued wood jolnts depend for their strength chlefly upon mechanical adhesion. However, Browne and Brouse's work shows "that much stronger wood joints can be made with both 'strong' and 'weak' glues than were thought representative by the advocates of mechanical adhesion hypothesis, provided that the joints are made by the gluing procedure used by the adherents of the specific-adhesion theory. The theory that specific adhesion is essential for satisfactory wood-gluing is confirmed." 
This work was of considerable interest to this project since the adhesives used to test this theory were sodium silicate and animal glue. These adhesives were first chosen for investigation here as a binder for the wood mixture in making fiberboard.

The physical characteristics of a fiberboard may be considered to depend upon the following variables:

1. The time in the pregs

2. The temperature of the press

3. The pressure of the press

4. The treatment while the fiberboard is in the press

5. The size of the wood waste

6. The molsture content of the adhesive

7. The amount of drying after the fiberboard is taken from the press

8. The type of surface material

9. The composition of the adhesive. 
EXPERIMENTAL PROCEDURE AND RESULTS 
It must be remembered that most of these variables are closely interrelated so that any one of them cannot be considered singly but must be considered in conjunction with one or more of the other varlables.

The time in the press was varied from three minutes to two and a half hours. Most of the adhesives set in a comparatively short time. The length of time the sample was in the press was largely necessary for the proper drying of the board.

The temperature of the press was determined by the type of adhesive used. In general, it was found that the highest temperature that would not weaken the glue was the best to use since this would give the driest sample in the shortest time. The temperatures used ranged from room temperature $\left(75^{\circ} \mathrm{F}.\right)$ to $350^{\circ} \mathrm{F}$.

The pressures ranged from 150 to $900 \mathrm{psi}$. A suff1ciently high pressure had to be used to compress the wood mixture so that the individual wood particles would be close enough to adhere together. If too high a pressure were used the adhesive would be squeezed out and a condition similar to a "lean joint" would occur. It can be seen that the pressure depended on the fluidity of the adhesive used. This, in turn, would depend on the temperature used and on the composition of the adhesive.

The size of the chips and sawdust could not be controlled very closely. The wood mixture obtained from the 
General Box Company was used without any size separation. When the effect of any variable was studied, the chips and sawdust were taken from the same batch and carefully mixed so that their size distribution would not vary greatly for any particular group of fiberboard samples made.

The ratio of the chips and sawdust first used was two parts of chips to one part of sawdust. However, it was found that some of the chips contained a large amount of fines. Using these chipg a much stronger board could be made without the addition of any sawdust.

The molsture content of the adhesive was of prime importance. The adhesive had to be fluid enough to cover the wood mixture effectively without using an excessive amount of adhesive. On the other hand, an adhealve of a low solids content would have a high fluidity but would have two disadvantages; first, the glue bond would be weakened, and secondly, the drying perlod would be extended.

All the fiberboard samples made required additional drying after they were removed from the press except the type made with an asphalt emulsion. This drying had to be carefully controlled, otherwise warping would occur.

It was found that the liner used gave the board about 25\% or more of 1ts strength. Therefore, the stronger the type of liner used, the stronger the resulting board would be.

The discussion of the experimental work done will be divided as to the type of adhesive used. The types of adhesives 
used and the company from which they were obtained are listed below:

\section{Types of Adhesives}

1. Sodium silicate was used in a $40 \%$ solution by weight. This solution came from the Philadelphia quartz Company and was the same as used in the production of corrugated boxes by the General Box Company. The $\mathrm{S}_{1} \mathrm{O}_{2} / \mathrm{Na}_{2} \mathrm{O}$ ratio was $3.2 / 1.0$.

2. Animal glue was obtained from the Peter Cooper Corporation, Gowanda, N. Y. and was the normal wood gluing type.

3. Two types of cornstarch were used:

(a) Staley \#2 was obtained from the General Box Company •

(b) A chemically processed starch was obtained from the Corn Products Refining Company, New York.

4. An aqueous $30 \%$ glyoxal solution obtained from the Carbide and Chemicals Corp.

5. A processed casein was used from the Casein Co. of America.

6. Three grades of rosin, $D, K$, and $W W$, were obtained from the Newport Industries, Inc., New York, N. Y.

7. A liquid urea formaldehyde resin was used with a wheat flour extender. Th1s was obtained from the casein Company of America and was used with catalysts M-28 and MO 400. 
8. The following types of asphalt emulsion were tried:

(a) Flintkote C-13-HPC, penetration of base: 50

(b) "N-13-HPC, " " 85

(c) Bitucote Clay type, penetration of base: $30 / 35$

(d) "Soap " " 50

(e) " " " " 75

(f) " Clay " " "

(B) " Soap " " 100

(h) Philip Carey, Ebontex, " " 50/60

(1) Asphalt emulsion obtained from the Highland Construction Company, Loulsville, of penetration 100/150.

The chips and sawdust were obtained from the General Box Company. This wood waste was used as received, with no attempt made to take the chips or sawdust of any fixed size. The adhesives were used singly and in combination. In the discussion of each type of binder the influence of the variables listed on page 13 will be mentioned.

The following things were taken into account in setting up the requirements for the ahesive binder. (1) The manufacturing processes now used in making commerclal fiberboard products; (2) the nature of the fiberboard needed for wirebound boxes, and (3) the preliminary investigation made by John Birkel. The requisites for the adhesive binder are: 
Requirements for Adhesive Binder

(1) The adhesive should cost about one to one and a half cents per pound.

(2) The adhesive must have good spreading qualities.

(3) The adhesive must wet the wood surfaces. It must not penetrate too deeply into the wood, otherwise an excessive amount of adhesive would be used whlch would result in a heavier board.

(4) The adhesive solution should have high solids content. Most of the solvent has to be evaporated while the fiberboard is in the press in order to get a flberboard of reasonable strength.

(5) The adhesive solution should have small corrosive properties and a reasonably long working life.

(6) Due to the heterogeneous nature of the wood filler, the adhesive must be able to retain a good part of 1 ts maximum bonding strength; 1 . $e .$, when it binds materials with smooth gluing surfaces.

(7) An adhesive whose sollas had a reasonably low density would be preferred since a light weight fiberboard is desired.

(8) The adhesive should have reasonable moisture resistance and also be water repellent.

(9) Because of the expendible nature of the container that would be made from the fiberboard, the Iife of 
adhesive bond does not have to be particularly long.

(10) Since paper liners are used the color of the adhesive is of little importance.

\section{Laboratory Procedure}

Some difficulty was experienced in the actual construction of fiberboard panels in the laboratory. The form that was first used consisted of a rectangular pan 5 by 8 Inches which had sheet metal sides one inch deep, attached to a wooden bottom. The top was a board which fitted loosely in the frame. It was found that the strength of the board was affected appreciably by the molsture content of the board when it was taken from the press. About forty to fifty grams of water, which acted as a vehicle for the adhesive, had to be evaporated from an 8 by 5 inch sample to give a fiberboard of about 5\% molsture content or less. This f1rst form used almost totally enclosed the flberboard while it was in the press. The sample had to remain in the press at least thirty minutes in order for enough water vapor to diffuse from it to make the fiberboard sufficlently strong. Since the fiberboard was separated from the heated platen by a half inch of wood, the heat transferred was low. Therefore, a new form was made which consisted of a wooden frame which fitted around a metal plate that formed the bottom. This frame was not connected to the metal plate. The wooden top was used as before. This form produced samples in a shorter press time that were considerably 
stronger. Later it was found that this form allowed the adhesive to set enough after one minute so that the form could be removed completely from the fiberboard without having the filler squeezing from the board. In this procedure the sides of the panel were exposed to the atmogphere allowing the water vapor to diffuse from the board in a much shorter time. Since the platens were not separated from the flberboard, the adhesive could set quicker and more evenly.

The next improvement in technique was to raise and lower the platen continually after the form had been removed. This new method removed the water from the board in a much shorter press period. A dry board could be produced this way in about ten minutes that was as dry as that produced in the first form in two hours. Moreover, the pressure of the press was reduced from 400 psi to 200 psi. This intermittent pressure method of making flberboard showed that a constant pressure on the board was not needed while the board was drying. Therefore, It was believed that this type of fiberboard can probably be made using heated rollers instead of a plywood press.

The procedure for making an asphalt type fiberboard panel 5 by 8 inches and $3 / 16$ inch thick was as follows: The chips and sawdust are mixed in proportion of 54 grams of chips and 27 grams of sawdust. Next 7 grams of water was added to 10 grams of starch. 55 milliliters of sodium sil1cate to the starch paste and the mlxture was stirred unt1l a smooth solution was formed. The mall amount of water that was first added to 
starch is necessary to make this solution free of lumps. It also gives the adhesive mixture the proper viscosity. Ten grams of asphalt emulsion was then added to this mixture. The working I1fe of this adhesive mixture was found to be at least three days. However, once the adhesive was added to the wood mixture, the material had to be put in the form within five minuteg and compressed. This mixture was then poured into the form on top of the bottom liner which was coated with sodium silicate. Care was taken to get a uniform mat. The top liner was likewise coated with sodium gilicate before being put on top of the filler. Next the wooden top was put on this liner and the board was placed in the press. In this case the temperature of the presg was $130^{\circ} \mathrm{C}$. After one minute the form was removed; the sample was then left in the press for nine minutes longer. During this last period the platen was continually raised and lowered. The maximum pressure was 200 psi. This type of board required no additional treatment. The fiberboards that aid require drying were usually put in a dryer at $105^{\circ} \mathrm{F}$ for twenty-four hourg.

\section{Discussion of Testa}

\section{All fiberboard samples that were made were five} inches wide and eight inches long and contained the same welght of wood mixture. Ths thickness varied from $3 / 16$ to $1 / 4$ of an 1nch. Therefore, the adhesive composition of each board will

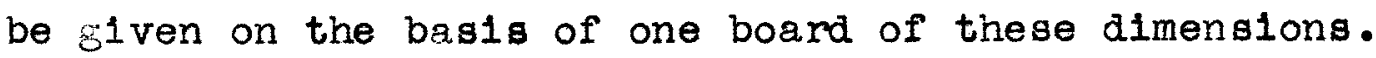


Since the weight - strength relationship is more important than the weight - thickness factor, tensile flexure and impact strength will be reported on a basis of one inch width of board. All tensile testa were made on a Dillon Tester using $13 / 4$ inch jaws. All samples tested in tension were five inches long and $13 / 8$ inches wide. Flexure tests were made on the same testing machine using center bending on a four inch span. These test samples were seven inches long and one inch wide. Impact tests were made by dropping a 0.90 pound bolt head f1rst on the center of the sample tested. A plpe was used to guide the welght on the center of the sample. The samples tested were eight inches long suspended on blocks six inches apart. The helght the weight was dropped was recorded. Impact strengths are reported in foot-pounds per inch of width.

\section{Adhesive Compositions}

1. Sodium Silicate

Sodium silicate will be the flrst discussed since about ninety-five per cent of the adhesive compositions tried contained a large amount of sodium silicate. This adhesive had previously been used by John Biricel in combination with animal glue. Using this combination, a board had been produced which was falrly atrong. Its chlef disadvantages were its poor water resistance and the careful drying it required. Sodium silicate is one of the cheapest industrial adhesives used; the cost is about one cent per pound. Sodium silicate was used in 
a 410 Baume aqueous solution which contained about $40 \%$ solids by weight. This is a colloldial solution which contained about 3.2 to 3.3 parts of silica to one part of soda. This is the type of sodium silicate that is widely used in the production of cormugated paperboard. This adhesive sets quickly when a small amount of water is removed from the sllicate solution. Before the adhesive actually sets the viscosity of the solution rapldiy increases. The vicsocity of a $62.4 \%$ water solution is 1.8 poises. When $1.1 \%$ of water is evaporated the viscosity becomes 7.5 polses, when $0.3 \%$ more water is evaporated it is 11.1. The removal of a very small amount of water at this point will produce a semi-solid sillcate. This adhesive has a bond strength of about $1000 \mathrm{ps}$. when dry. Sodium silicate is a widely used adhesive additive. It is highly resistant to heat and to molding and increases the working life of the glue. By slightly varying the ratio of silicate to soda the rate of set, depth of penetration, stiffness, and solubility of bond can be varled. The main disadvantages of the use of sodium silicate as an adhesive is its poor molsture resistance and its high alkalinity. Sodium silicate has a buffer action in an aqueous solution. The pH of 1ts adhesive solution varies from 11 to 12. However, this does not prevent it from being easily handled. It will mix well with most adhesives, but it cannot be mixed with organic solvents since this causes the sodium silicate to precipitate out of solution. This is attributed to the dehydration of the sillcate by the organic solvent. After it has 
set it has slight thermoplastic properties $(30,31)$.

Sodium silicate mixed easily with all the adhesives used except animal glue and the urea formaldehyde adhesive. The two major properties it gave the board were stiffness and cheapness. Most of the other adhesives that were tried were used to modify sodium silicate, primarily to increase its molsture resistance and secondarily to increase its strength.

Several samples of f1berboard were made with the wood mixture and sodium silicate with no other adhesive. The best board of this type had the following composition based on a 5 by 8 inch panel:

Formula 1

54 grams of chips
27

65 milliliters of sodium silicate

This board was fairly rigid and tested about 260 pounds per inch of width in tension and about 23 pounds per inch of width in flexure. When this board was exposed to relative humidity of about $80 \%$ at $800 \mathrm{~F}$ for about two weeks it lost about one third to one half of 1ta original dry strength.

2. Modifications of Sodium Silicate Adhesive

There are many references in the literature concerming additives for sodium silicate in order to increase 1ts molsture resistance (27). The increase in moisture resistance is usually due to the formation of an insoluble 
silicate. The following additives that were tried are:

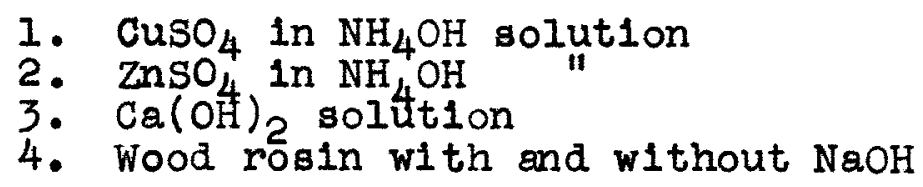

The first three additives form an insoluble

silicate; the rosin forms a pale yellow solution which is much like the original silicate solution. The compositions used for a 5 by 8 inch panel were:

Formula 2

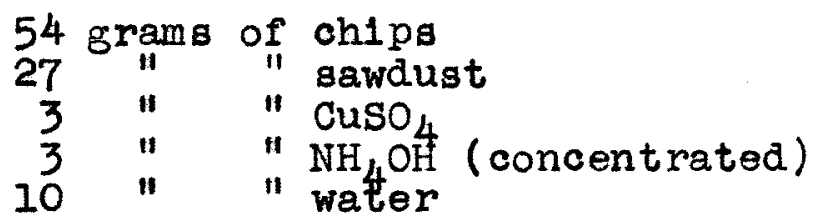

60 milliliters of sodium sillcate.

Formula 3 This was the same as Formula 2, except $\mathrm{ZnSO}_{4}$ was used in place of $\mathrm{CuSO}_{4}$.

Formula 4

$$
\begin{aligned}
& 54 \text { Grams of chips } \\
& 27 \text { " " sawdust } \\
& 44 \text { " Ca(OH) } \\
& 12 \text { " water } \\
& 65 \text { milliliters of sodium silicate. }
\end{aligned}
$$

The CuSO $4^{-8 i l i c a t e,} \mathrm{ZnSO}_{4}$-8ilicate, and $\mathrm{Ca}(\mathrm{OH})_{2}-$ silicate type fiberboard had tensile strengths of 220,235 , and 240 pounds per inch of width respectively. The large amount of water needed to make the adhesive solution fluid enough to cover the wood mixture effectively caused the board to have these low tensile strengths.

Wood rosin is widely used in the paper industry as sizing to improve the binding properties and molsture resistance of the wood pulp. The three grades of rosin uged were $D, K$, and WW. The rosin was used in two ways. One method 
was to disgolve the rosin in an organic solvent. This rosin solution was then added to the wood mixture and next the silicate was added. The other method was to add rosin directIy to the silicate solution. Rosin consists largely of abietic acid; this is a high molecular weight organic acid which will react with sodium silicate to form sodium resonate. This solution was made by adding finely powdered rosin to silicate and stirring for fifteen minutes until a transparent, pale yellow solution was formed. This solution was more viscous and slightly less alkaline than the pure silicate solution. The best sllicate rosin composition was: Formula 5

$$
\begin{aligned}
& 54 \text { grams of chips } \\
& 27 \text { " " sawdust } \\
& 5 \text { " " rosin } \\
& 65 \text { milliliters of sodium silicate. }
\end{aligned}
$$

This board had a tensile strength of 280 pounds per inch of width. The composition of the mixture using rosin and an orsanic solvent was:

Formula 6

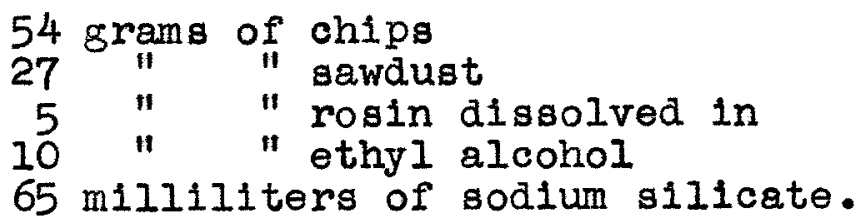

The other orsanic solvents tried were carbontetrachloride and turpentine. This board had a tensile strength of about 300 pounds per inch of width. The addition of the rosin increased the wet and dry tensile strength about ten per cent.

3. Adhesives Used in Combination with Sodium Silicate. Animal slue and sodium silicate adhesive mixture was 
the first binder used that produced a board of favorable strength and rigidity. The best composition found a.s formulated by J. Birisel was:

Formula 7

$$
\begin{aligned}
& 54 \text { grams of chlps } \\
& 27 " \text { " sawdust } \\
& 3.4 " \text { " animal glue } \\
& 5.4 " \text { " water } \\
& 55 \text { milliliters of sodium silicate. }
\end{aligned}
$$

The water and glue were first mixed and heated to $180^{\circ} \mathrm{F}$. The glue was then added to the wood mixture. Next the silicate solution was added and the panel was put in the press at $400 \mathrm{psi}$ and $200^{\circ} \mathrm{F}$. If a higher temperature than this was used, the anlmal glue would be weakened. This type of board required a considerable amount of drying when 1t was removed from the press. The average tensile strength of the fiberboard was 270 pounds per inch of width and the flexure atrength was 27 pounds per inch of width. The animal glue appreclably added strength and stiffness to the board but did not noticeably make the board more moisture resistant. 4. Starch and Sodium Sillcate Adhesive

starch was found to be a very effective additive for sodium slifate. Since the addition of starch to the silicate solution gave very favorable results, a short aiscusgion of whe $g \in n \in r a l$ use of starch is in order.

Tue E\&yptians first made paper by dinding thin sheets of papyrus together with a starch base adhesive. It nas also been reported that the Chinese used starch as a wood adhesive. In 1891 a patent was granted to Higgins on an adhesive of dex- 
trin and borax, another in 1894 to wagner on an adhesive of dextrin, copper sulfate, sugar and nitric acid. In 1908 a U. S.patent was 1ssued to Ferkins for a starch glue to be used in wood working. Later the Perkins Company started commercial production of starch type glues for woodworking. At the present time starch is often processed before 1ts conversion into glue. This "processing" makes it more soluble by modifying the outer wall of the starch grain; it reduces Its water-absorbing quality and thus produces a glue of low water content; and finally, it produces a homogeneous uniform product. For the past hundred years many investigators have studied the chemical and physical nature of starch. Most investigators agree that the starch grains consist of an outer sac of alpha-amylose with an Inner substance of beta-amylose. This outer shell is insoluble even in hot water. The production of a paste consists in the swelling of the shell which ruptures and allows the water to dissolve the more soluble inner substance. The temperature necessary to produce this conversion is known as gelatinization temperature and varies with the source of the starch as well as the alkalinity of the solution. It has been found that when a starch suspension Is overheated, a chemical change occurs which weakens the adheslve $(26,32,33)$. However, it has been found previously as well as in this project that the starch silicate adhesive forms a stronger and more moisture resistant bond when it is heated to $130^{\circ} \mathrm{C}$ after it has set if it is not held at this 
temperature too long.

Starch can be easily mixed with sodium silicate by first moistening it with water and then stirring it well with the silicate solution. This starch-silicate mixture has been stored for several days with no weakening of its adhesive strength. This adhesive has very good spreading qualities. The starch-silicate fiberboard has more molsture resistance and strength than a board made with either the silicate or starch adhesive used singly, but it is not as moisture resistant as is desired. The best starch-silicate composition was:

Formula 8

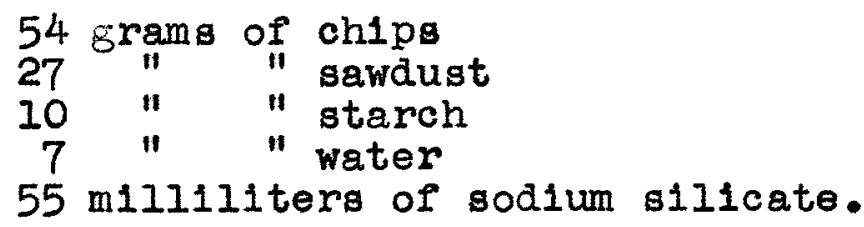

This board had a tensile strength of about 325 pounds per inch of width and a flexure strength of 28 pounds per inch of width. The principal disadvantage of the silicate-starch adhesive was its poor moisture resistance and the difficulty that occurred in drying the fiberboard after it was taken from the press. This drying was done at $105^{\circ} \mathrm{F}$ for twenty-four hours. If a higher temperature were used warping would occur and the board would be weakened. After this board had been dipped in water for five minutes 1t lost about $60 \%$ of 1 ts original ary tensile atrength. If the board was left in a humld atmosphere ( $90 \%$ relative humidity at $75^{\circ} \mathrm{F}$ ) for fourteen days the board was noticeably thicker and usually lost about 30 to $40 \%$ of its 
original dry strength.

Large panels 36 by 25 inches were made of this composition (Formula 8) on a regular plywood press at the General Plywood Company, Loulsville, Kentucky. These panels were later used as face material for wi re-bound boxes which were tested at the Package Research Laboratory, at Rockaway, New Jersey .

Twenty-one of these panels were made. Little trouble was experienced in the actual construction of the panels, but some difficulty was had in drying these panels properly. Since there were no facilities at the General Plywood Plant for drying the fiberboard, the panels remained in a moist condition for as long as forty-eight hours before they were dry. Some warping did occur. The small panels of the same composition made here in the laboratory were much stronger and more compact than the large panels. Mr. Henry A. Wolsdorf, Vice-President of the stapling Machine Company, described the tests made on the boxes made of fiberboard (25). Mr. Wolsdorf stated that a similar box made with $1 / 8$ inch gum veneer should go twenty falls to the first serious fallure in the "rough handing test" and from thirty to forty falls before final failure. The best fiberboard box went fourteen falls to the first serious fallure and thirty-one falls to final fallure. Therefore, the box was declared not suitable. In the appendix a copy of the report made by Otto Ingram of the Package Research Laboratory, who directed these tests, is also included. Mr. Insram reports 
that severe wire cutting and rupture of the material along the edges occurred during these tests. This was due to the porous1ty of the board, particularly near the edges.

This method of testing containers of this type has been falrly well standardized. This test is made by loading the container to be teated with shifting weights and then putting it in a revolving hexangular drum. The cleats, which are on the Inside surface of the drum, cause the box being tested to undergo a series of falls. The number of falls necessary to cause the first serlous failure and the number necessary for final fallure are recorded.

5. Glyoxal-Starch-Silicate Adhesive

Starch is chemically defined as a polysaccharide. Each unit of this polymer has one "OH" radical which will react with an aldehyde group. Since the glyoxal molecule has an aldehyde group on each end, it is able to form a polymer with starch which has more desirable adhesive properties than the ordinary starch polymer. The principal advantage of the glyoxal-starch adhesive is 1ts moisture resistance. The use of glyoxal in adhesives is fairly recent $(34,34,36)$. It is usually used in a stablilized $30 \%$ aqueous solution.

In order to find the properties this adhesive would give to the fiberboard, a glyoxal-starch fiberboard was made of the following composition: 
Formula 9

$\begin{array}{lll}54 & \text { grams } & \text { of chlps } \\ 27 & " 1 & \text { " sawdust } \\ 30 & \text { " } & \text { " } \\ 33 & \text { " gater } \\ 55 & \text { " } & \text { " starch }\end{array}$

The composition of the glyoxal-starch-silicate

board was:

Formula 10

$$
\begin{aligned}
& \begin{array}{l}
54 \text { grams of chips } \\
27 \text { " }
\end{array} \\
& 4.5 \text { " "30\% glyoxal solution } \\
& \begin{array}{lll}
5 & \text { " " " water } \\
10 & \text { " starch }
\end{array} \\
& 50 \text { mill11iters of sodium silicate. }
\end{aligned}
$$

The result of the wet and dry tensile and dry

flexure tests are given in the following table in which these two types of fiberboard are compared with the starch-silicate type (Formula (8):

Table I Comparison of Tensile and Flexure Strengths of GlyoxalStarch, Glyoxal-Starch-Silicate, and Starch-Silicate Fiberboard

\begin{tabular}{cccc}
$\begin{array}{c}\text { Composition of } \\
\text { Fiberboard }\end{array}$ & $\begin{array}{c}\text { Tensile strength in } \\
\text { lbs/1nch of width }\end{array}$ & $\begin{array}{c}\text { Flexure strength in } \\
\text { lbs/inch of width }\end{array}$ \\
\hline Formula No. & Dry & Wet* & Dry \\
Glyoxal-starch & 330 & 160 & 35 \\
$\begin{array}{c}\text { (9) } \\
\text { Glyoxal-starch- }\end{array}$ & 320 & 150 & 30 \\
silicate (10) & 300 & 120 & 28 \\
$\begin{array}{c}\text { Starch-silicate } \\
\text { (8) }\end{array}$ & & &
\end{tabular}

* The "wet" strength of the board is hereby defined as the strength the board has after it has been immersed in water for five minutes. 
It can be seen from Table I that the best modification of the fiberboard by the addition of glyoxal was the increased stiffness of the board. The flexure strength wa increased from 28 to 35 . The wet and dry tensile strength was only slightly inc reased even when a large amount of glyoxal was used.

5. Urea Formaldehyde Type Adhesive

A fiberboard using a liquid type urea resin was made of the following composition:

Formula 11

$$
\begin{aligned}
& \begin{array}{l}
54 \text { grams of chips } \\
27 \text { " sawdust }
\end{array} \\
& 30 \text { " "urea resin } \\
& 30 \text { " "wheat flour } \\
& 30 \text { " " water } \\
& 4 \text { " "catalyst M28. }
\end{aligned}
$$

This board was made with a low amount of wheat flour extender and no silicate in order to find how strong a fiberboard could be made with an adheslve binder and an untreated wood mixture. The dry tensile strength of this board averaged about 420 pounds per inch of width.

A board made using economical adhesive mixture had the following composition:

Formula 12

$$
\begin{aligned}
& 54 \text { grams of chips } \\
& 50 \text { milliliters of sodium silicate } \\
& 27 \text { grams of sawdust } \\
& 18 \text { " " wheat flour } \\
& 18 \text { " water } \\
& 4.5 " \text { " urea resin } \\
& 0.5 " \text { catalyst MO-400 }
\end{aligned}
$$


Since the urea resin would have caused the sodium silicate to precipitate out of solution if they were mixed together, " $a$ " and " $b$ " were first made and then combined. This board was made with the maximum amount that could be used economically. The following table shows a comparison of the two urea type fiberboards:

Table II Comparison of wet and Dry strengths of the Glyoxal-Type Fiberboard

\begin{tabular}{ccccc}
$\begin{array}{c}\text { Formula } \\
\text { No. }\end{array}$ & $\begin{array}{c}\text { Tensile Strength } \\
\text { In lbs/inch of } \\
\text { width }\end{array}$ & $\begin{array}{c}\text { Flexure strength } \\
\text { in lbs/inch of } \\
\text { widh }\end{array}$ & $\begin{array}{c}\text { Impact strength } \\
\text { In ft-ibs/inch } \\
\text { of widh }\end{array}$ \\
\hline & Dry & Wet* & Dry & Dry \\
11 & 420 & 360 & 31 & 1.05 \\
12 & 320 & 150 & 27 & 0.95
\end{tabular}

* The "wet" tests were made in the same way as on the glyoxal fiberboard.

The urea formaldehyde board made with a small amount of extender showed that a fiberboard of high strength could be produced from an untreated wood-mixture of chips and sawdust. However, this adhesive was too expensive to use in this formulation (11). A board of similar strength and molsture resistance made with cheaper adhesive would be satisfactory for box material. When the urea formaldehyde adhesive was used in an economical mixture (Fomula 12), it did not appreciably strengthen the board. Both of these boards required as much 
and as controlled drying as the starch-silicate board. 7. Adhesives which contained Asphalt Emulsion

At this point a board had been developed which was reasonably strong but had two serious disadvantages: F1rst, it had low moisture resistance, and secondly, it had to be carefully dried. A similar problem occurred during the first part of the war in the development of overseas containers. This problem was solved by the use of synthetic resin adhesives with and without the use of a cheaper asphalt emulsion extender. When the asphalt emulsion was used as an extender of the more expensive resin adhesive, the moisture resistance of the container was not impaired. The asphalt type fiberboard made on this project proved to be the best. A discussion of the nature of the asphalt emulsion furnishes some of the reasong why the characteristics of the board made with asphalt emulaion were so favorable.

Asphalts are defined by the American Society of Testing Materials as "Black to dark brown solid or semi-solld cementious materials which gradually liquify when heated, in which the predominating constituents are bltumens, all of which occurs in the solid or semi-solid form in nature or are obtained by refining petroleum, or which are combinations of the bitumens mentioned, with each other or with petroleum or derivatives thereof." Bltumens are defined as "Mixtures of hydrocarbons of natural or pyrogeneous origin, or 
combinations of both, frequently accompanied by their nonmetallic derivatives which may be gaseous, liquid, semisolid, or solid, and which are completely soluble in carbon disulfide." Water emulsions of asphalt are made by intimately mixing wetting agents, asphalt, and water $(34,37)$. The asphalt emulsion gave the fiberboard many desirable properties:

1. Asphalt is very insoluble in water. When it is finally divided as it is an emulsion it gives the material that 1t covers good water repellency.

2. Asphalt is used commercially in very large quantities. The cost per pound is very low, especially when it is used in a water emulsion.

3. Asphalt is thermoplastic. The asphalt type fiberboard was made at $1300 \mathrm{C}$. At this temperature it is believed that the heat, tosether with the steam formed, causes the lower bolling constituent of the agphalt to be removed leaving a harder asphalt deposited. It was found that, in general, the harder the asphalt used the stronger was the board made from it. 4. The asphalt emulsion mixed well with the starchsilicate solution. The resulting solution had a working life of at least four days after it was prepared.

The best asphalt type fiberboard composition was found to be as follows, for a 5 by 8 inch panel: 
Formula 13

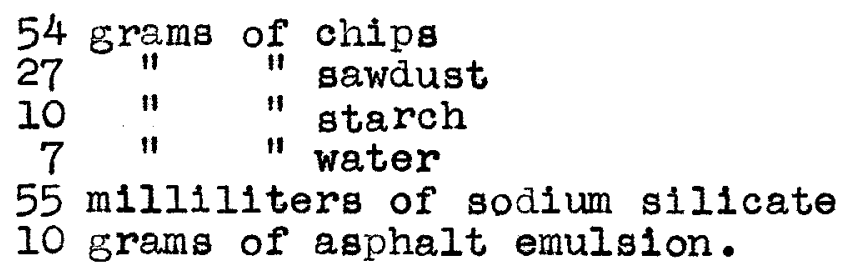

This board had the following advantages:

1. The board required no additional dry ing when 1t was removed from the press.

2. Tensile strength of the board was increased about 15 to 20 pounds per inch of width by the addition of the asphalt emulston.

3. Very little, if any, loss of strength occurred when the board was left in an humid atmosphere.

4. The adhesive had good spreading properties, even though it had a high solid content.

5. The addition of the agphalt emulsion caused the amount of delamination to be reduced considerably.

Three fiberboard samples were made using the composition of Formula 13 of each type of asphalt emulations listed on page 13. The Flintkote emulsions and Bitucote emulsions of $30 / 35$ penetration base gave the strongest f1berboard. The tensile strength averaged about 300 to 315 pounds per inch of width. The results indicated that the harder the asphalt used, the stronger was the fiberboard produced in a range of penetration hardness tested.

In the early part of the work on this project it was found that the size of the chips and sawdust had some effect on the strength of the board. Whenever the effect of any one 
of the variables of press conditions or adhesive compositions was studied, care was taken to use the chips and sawdust from the same batch received from the General Box Company. It was noticed that a certain batch of chips, when used as a filler, gave unusually low and inconsistent results. A gize analysis of the chips mixture showed that it had a considerable portion of fines; these fines were of the same relative size as the sawdust used. Therefore, these chips were used alone as a filler with no sawdust added. The composition of a 5 by 8 inch board was:

Formula 14

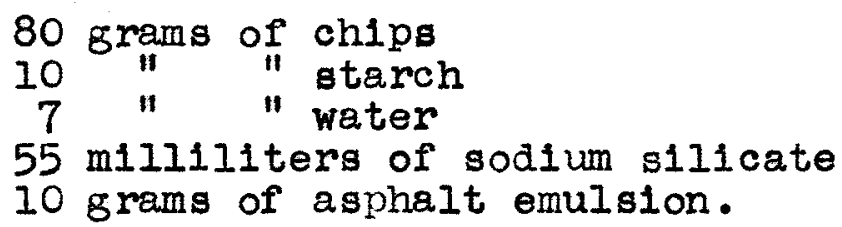

This board was about 30 to $40 \%$ stronger than that made with the same adhesive composition but with sawdust added. In the chips mixture used, the chips had the same variation in size as that used before, except there were more fines. Some chlps were as thick as $1 / 16$ of an inch and about one inch long. This is the type of board that gave the best test results and is the one recommended as face material for wire-bound boxes. It had been noticed that in all the types of fiberboard made, some delamination occurred. This did not happen regularly; about one-fourth to one-third of the boards made had one or two spots where some parting had occurred. Usually this delamination occurred while the sample was in the press. Therefore, the asphalt-starch-silicate type fiberboard was made with different compositions and under different press conditions in 
order to determine the cause and possible correction for delamination. Each board was cut in strips about one inch wide and the sides were inspected for possible delamination. About thirty fiberboard samples were examined in this way and the following conclusions were made:

1. An increase in asphalt content caused the decrease of delamination occurring. However, when the asphalt content was above a certain value the strength of the board was decreased.

2. The platen must be lowered at least every fifteen seconds during the last five minutes the sample is in the press, otherwise delamination may occur.

3. Delamination was probably caused by either the formation of a vapor bubble in the board or by too rapid or uneven drying of the fiberboard while it was in the press. 4. In some samples holes about $3 / 32$ of an inch in diameter were punched in the fiberboard which were spaced about $11 / 4$ to $11 / 2$ inches apart. The sample was perforated in this way after it had been in the press for five minutes. It was then replaced in the press for five more minutes. These holes reduced delamination almost completely. Since delamination occurs in only a few cases, it is believed that there would be sufficient control of the operating variables in commercial production to reduce delamination completely without perforation of the board. 
8. Fiberboard made with Hydrolyzed Wood Waste When wood is cooked in an acid or basic solution the wood structure breaks down giving cellulose, Iignin, and the other constituents of the wood. These, in turn, are modified depending on whether an acid or basic solution is used. Some of these break-down products have good adhesive properties. The important adhesives that are produced in the hydrolygis of wood are lignin, the hemi-celluloses, starch, rosin, and dextrine (38).

A two per cent sulphuric acid solution as well as a two per cent sodium hydroxide solution were used in effecting the hydrolysis of the chips/sawdust mixture. The wood mixture was added to the acid or basic solution and cooked for three hours under atmospheric pressure. The water was then evaporated after the solution was neutralized until the materlal left wag just tacky enough to adhere together. Formula 15

$$
\begin{aligned}
& 54 \text { grams of chips } \\
& 27
\end{aligned}
$$

Enough acid or basic solution (2\%) by welght to cover the wood mixture

This hydrolyzed mixture was put in the form and compressed at $400 \mathrm{ps} 1$ at $1000 \mathrm{C}$ until a dry board was produced. Since this board was made with the form that totally enclosed the board, the time in the press was usually a bout forty-five minutes. The board produced by this method showed that a considerable amount of adhesive products had been formed during the hydrolysis, but the solid material that 
remained was very brittle and had little strength. This fiberboard had about thirty per cent of the tensile strength of the starch-silicate board. If more work had been done using this process, the tensile strength may have been increased, but it wa obvious that this type of board would be too brittle for box material.

A similar board was made using an extracted lignin obtalned from the Mead Corporation, Chillicothe, Ohio. This board had the following composition:

Formula 16

54 8rams of chips

60 milliliters of sodium silicate

5 grams of lignin.

This board had a favorable tensile strength but also had the brittle characteristics of the board produced by the hydrolysis of the wood mixture. 
Table III Comparison of Dry Tension Tests of Fiberboard with Corrugated Paperboard and Wood Veneer

\begin{tabular}{|c|c|c|c|}
\hline Material Tested & $\begin{array}{l}\text { Formula } \\
\text { No. }\end{array}$ & $\begin{array}{l}\text { Tensile strength } \\
\text { in lbs/Inch of }\end{array}$ & $\begin{array}{l}\text { Temperature } \\
\text { of the press }\end{array}$ \\
\hline
\end{tabular}

A. Paperboard:

350\# C flute

100

200\# C flute

99

200\# B flute

114

B. Rotary cut gum veneer:

$1 / 8 \mathrm{Inch}$

$550-600$

1/7 inch

950-1000

1/6 inch

$1000-1200$

3/16 inch

$1550-1650$

$7 / 32$ inch

$1650-1700$

$1 / 4$ inch

$1700-1800$

C. Fiberboard:

Sodium sllicate

$1240-260$

110

Silicate-animal glue

$7 \quad 260-280$

Silicate modified with:

$\begin{array}{llll}\mathrm{CuSO}_{4} & 2 & 215-225 & 110 \\ \mathrm{ZnSO}_{4} & 3 & 230-250 & 110 \\ \mathrm{Ca}(\mathrm{OH})_{2} & 4 & 235-245 & 110 \\ \text { Rosin/Organic solvent } & 6 & 295-325 & 120 \\ \text { Rosin } & 5 & 270-295 & 110\end{array}$


Table III Comparison of Dry Tension Tests of Fiberboard with Corrugated Paperboard and Wood Veneer (Con't)

Material Tested Formula No.
Tensile strength in $1 \mathrm{bs} /$ inch of width

Silicate-rosin

starch

Silicate-urea

resin

Silicate-glyoxal

starch

S1I1cate-asphalt

Silicate-processed starch

Sillcate-staley

\#2 starch

flour

GIyoxal-starch

Hydrolyzed wood

Lignin-s111cate

Sil1cate-starchasphalt emulsion

Silicate-starch asphart emulsion (no sawdust added)
10

8

11

12

$290-320$

120

$290-310$

110

$305-320$

110

$270-280$

120

$210-230$

100

$290-310$

110

$400-420$

130

9

305-325

120

15

$100-140$

100

16

$250-265$

100

13

$300-315$

130

14

$400-440$ 
The tension tests are a good measure of the relative strength of different types of the fiberboard made for this project. However, it must be remembered that only a fraction of the tensile strength of wood can be utilized after it is fabricated by atapling or nailing. After wood veneer has been stapled or nalled together, it ugually fails by splitting along the grain. Due to the grainless nature of the fiberboard it fails in a truly fibrous manner even after it has been stapled or nalled together. Using the starch-silicate fiberboard (Formula 8) as a basis for comparison, the following table shows the relative tensile strengths of the fiberboard, the wood veneer, and the paperboard. The fiberboard is Ilsted in the order of its tensile strength with the weakest fiberboard ligted first. 
Table IV Comparison of Dry Tensile Strengths of F1berboard with Corrugated Paperboard and Wood Veneer.

Material tested

Formula No.

$\mathrm{CuSO}_{4}-\mathrm{g111 \operatorname {cate }}$

Processed starch-silicate

$\mathrm{ZnSO}_{4-8111 c a t e}$

Sodium sillcate

Lignin-silicate

s111cate-asphalt emulsion

Sillcate-animal glue

Silicate-rosin

Sillcate-urea resin

Silicate-Staley \#2 starch

Silicate-starch-asphalt

Glyoxal-3tarch

silicate-rosin-starch

silicate-rosin/solvent

Urea formaldehyde-flour

Silicate-asphalt-atarch

(with no sawdust)

Paperboard (average)

Wood veneer: $1 / 8$ inch

$$
\begin{aligned}
& 3 / 16^{\prime \prime} \\
& 1 / 4 " \prime
\end{aligned}
$$

Tensile strength of Fiberboard/tens.str. of Starch-Silicate board
16
2
0.35

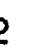
0.70
3
0.75
1
0.81
16
0.83
16
0.88
7
0.92
5
0.95
12
0.96
8
1.00
13
1.00
9
1.05
1.08
1.10
6
1.15
11
1.35
14
1.45
0.35
1.9
$5 \cdot 3$
5.9 
Table V Comparison of Flexure Tests of Corrugated Paperboard, Wood Veneer, and F1berboard

Material tested

Paperboard:

$$
\begin{aligned}
& 200 \# \text { C flute } \\
& 200 \# \text { B flute }
\end{aligned}
$$

9
8

Wood veneer:

$1 / 8$ inch

$1 / 6$ inch

35

72

Fiberboard:

Starch-silicate

(Formula 8)

$25-30$

Glyoxal-starch

(Formula 9)

$32-35$

Starch-cilicate-asphalt

(Formula 13)

$25-32$

Starch-silicate-asphalt

with no sawdust (Formula 14)

$35-43$ 
Table VI Comparison of Impact Tests of Wood Veneer with Fiberboard

Material tested Impact atrength in ft-lbs per inch of width

Wood Veneer:

$1 / 8$ inch

0.58

$1 / 7$ inch

0.65

3/16 inch

1.65

$1 / 4$ inch

2.00

Fiberboard:

Starch-s111cate

(Formula 8)

$1.00-1.40$

Glyoxal-starch

(Formula 9)

$1.15-1.45$ 
Although the tensile tests clearly show the relative strengths of the fiberboard, the flexure tests give a better measure of the value of the board for box face material. The flexure tests show that the chips, sawdust/starch-s1l1cate fiberboard (Formula 8) was about $20 \%$ weaker in flexure than $1 / 8$ inch wood veneer. The chips/asphalt-starch-silicate board (Formula 14) was about $20 \%$ stronger in flexure than $1 / 8$ inch wood veneer. It had over $50 \%$ of the flexure strength of $1 / 6$ inch wood veneer. This board (Formula 14) was about $3 / 16$ of an inch thick and welghed about one pound per square foot. Impact tests also give a good indication of the suitability of the fiberboard for box material. The fiberboard generally tested from 30 to $40 \%$. higher in impact than $1 / 7$ inch wood and only about $25 \%$ lower in impact than $3 / 16$ inch wood veneer.

The method used in making these tests is given previously • 
Table VII Comparison of Dry and Wet Tensile Strengths of Different types of Fiberboard

Fiberboard tested Tensile strength in lbs/inch of width

Wet strength Dry strength

$\begin{array}{lccc} & \text { Dry } & \text { Wet } & \\ \begin{array}{l}\text { Urea formaldehyde-flour } \\ \text { (Formula 11) }\end{array} & 420 & 360 & 0.86 \\ \begin{array}{l}\text { Urea formaldehyde-silicate } \\ \text { (Formula 12) }\end{array} & 320 & 145 & 0.46 \\ \begin{array}{l}\text { Rosin-silicate } \\ \text { (Formula 5) }\end{array} & 310 & 150 & 0.49 \\ \begin{array}{l}\text { Starch-sillcate-asphalt } \\ \text { With no sawdust } \\ \text { (Formula 14) }\end{array} & & & \\ \begin{array}{l}\text { Starch-silicate } \\ \text { (Formula 8) }\end{array} & 430 & 345 & 0.81 \\ & 315 & 140 & 0.44\end{array}$

The wet tensile strength of a flberboard is hereby defined as the strength of the sample after it has been immersed in water for five minutes. The asphalt type fiberboard (Formula 14) tested 260 pounds per inch of width in tension after fifteen minutes immersion. It must be remembered that .030 " jute linerg were used; therefore, the flberboard was almost completely soaked after fifteen minutes. After one week exposure to a high humidity atmosphere (about 95\% relative humidity at $70^{\circ} \mathrm{F}$ ), this asphalt was not measurably weakened. The urea-formaldehyde type fiberboard (Formula II) lost about 30 to $40 \%$ of its original dry strength under the same conditions of humidity. 
These tests showed that the fiberboard is slightly more porous than wood veneer. This asphalt type fiberboard was the only board made that had the desired water resistance. The water repellency of the board could probably be raised to any degree degired by the use of waterproof paper backing. of course, this backing would be pierced in the stapling and cutting operations, which would allow molsture to get to the inside of the board. However, it is believed that the asphalt type fiberboard has enough water reslatance and water repellency that it could undergo severe conditions of molsture if waterproof liners are used. For normal conditions the board 1s waterproof enough using .030" jute liners for general use.

Samples of the asphalt type fiberboard (Formula 14) were stapled together at the General Box Company and tested in the laboratory here on the Dillon Tensile Testing Machine. These tegts are important because they show what may be expected to do when 1t would be used as face material for w1re-bound boxes.

Three test specimens were made. In each case two boards 5 by 8 inches were stapled to one $1^{\prime \prime}$ square wood cleat. The first two test specimens were made by stapling the boards on the same side of the cleat in a "U" shape with the sides of the "U" formed by the boards and the cleat at the base of the "U". The third teat specimen wa made by stapling the board on opposite sides of the cleat. In all three test 
specimens the staples were about two inches apart. The first two test samples were tested by pulling the board pleces in one direction and the cleat in the opposite direction. Fallure occurred at a force of 660 pounds and 500 pounds in these two tests. The third specimen was tested by pulling the board pieces in opposite directions. At a force of 200 pounds the staples began to pull out. Later, the board pieces broke under the same amount of force. In all three cases two staples were used to bind a panel on the cleat.

In all three cases fallure occurred when the panel broke. In no case did delamination or severe wire eutting occur. 
SUMMARY AND CONCLUSIONS 
Most of the adhesive binders produced fairly rigid fiberboards. The urea-formaldehyde resin with an equal amount of wheat flour extender and the asphalt-starch-silicate fiberboards had sufficient strength and rigidity to make them sultable for face panels for wire-bound boxes. These were the only two types of fiberboard made that had a reasonable amount of water resistance. However, the urea-resin type adhesive was far too expensive for this type of a board. The asphalt-starch-silicate fiberboard (Formula 14) was the most favorable for wire-bound boxes. The advantages of the asphalt-starch-silicate adhesive binder are:

1. The adhesive solution had a very low cost on a weight basis.

2. The adhesive solution is stable, easily handed, and spreads well.

3. The adhesive bond is reasonably molsture resistant.

4. The adhesive gave the board strength, rigidity, and resiliency.

5. A constant pressure is not necessary for the fabrication of the board; therefore, this type of board can probably be made on rollers. 6. No additional drying is required after the board 1s taken from the press; warping does not occur. 


\section{LITERATURE CITED}

(1) Withan, G.S., Sr., "Moderm Pulp and Paper Making", p.325, Reinhold Publishing Corp., New York, (1942)

(2) Dryden, E. C.. Aronoviky, S. I., Jarnel, T. D., Paper Ind. Paper World, 21, 972 (1939) (Abstract only)

(3) Andrews, Oliver B., U. S. Patent 1,841,775, Jan. 19, 1931. (Abstract only)

(4) Nevin, James V. (to Pacific Lumber Co.) U. S. Patent $1,899,768, F e b .28,1932$. (Abstract only)

(5) Sheeley, H. A. (to Tulfide Products Corp.) U.S. Patent 2,222,633, Nov. 26, 1941.

(6) Dee, Herbert C., U. S.Patent 2,338,685, Jan. 4, 1944. (Abstract only)

(7) Walter, Henry E., and Heritage, Clark C. (to Wood Conversion Co.) Can. 421,889, Aug. 1, 1944.

(8) Dav1s, W. S., U. S. Patent 2,355,278, Aug. 8, 1944.

(9) Weber, Charles G., Ind. Engr. Chem., 27, p.896 (1935).

(10) Gibson, A. G., Ind. Engr. Chem., 22, p.223 (1930).

(11) Hind, R. R., Sugar News, 7, No. 1, (1926). (Abstract only)

(12) Sweeney, O. R. and Amola, L. K., Iowa State Coll. Agr. Mech. Arts Bull., No. 98 (1930)

(13) Sweeney, O. R., Hartford, C. E., Richardson, R. W. and Whittemore, E.R., Ibid, No. 182 (1931)

(14) Mason, W. H., U. S.Patent 2,234,126, March 4, 1941.

(15) Mason, W.H., U. S.Patent 2,234,788, March 11, 1941.

(16) Mason, W. H., Boehms, R.M., Simpson, G. C., (to Masonite Corp.) U. S. Patent 2,317,930, Apri1 29, 1943.

(17) Boehms, R.M. (to Masonite Corp.) U. S. Patent 2,224,135, Dec. 10, 1941.

(18) Taft, Philip B., Paper Trade Journal, 115, No. 16, (1942). 
(19) Barker, H. T., Paper Trade Jourmal, 120, No.12, 47,(1945)

(20) Killinger, J. E., Paper Trade Journal, 117, No. 19,(1943)

(21) Lorenzin1, E. M., Paper Trade Joumal, 118, No. 21, (1944)

(22) Lathrop, E. C., Ind. Engr. Chem., 22, p.449, (1930)

(23) Hutcheon, N. B., "Report of Interview w1th Dr. Barshfeld", Pb. 19699, British Intelligence Objectives SubCommittee, London (1945)

(24) De Luca, J. A., Trans. A. S. M. E., 69, No. 2163 (1947)

(25) Private correspondence, Henry A. Wolsdorf, Nov., 1946

(26) Perry, T. D., "Modern Wood Adhestves", p.16, P1tman Pubiishing Co., New York, (1944)

(27) Braude, Felix, "Adheslves", p.I., Chemical Publishing Company (1943)

(28) De Bruyne, N. A., "A1re raft Engineer", 18, 51, London Dec. 1939. (Abstract only)

(29) Browne, F. L., and Brouse, Don, "Nature of Adhesion between Glue and Wood", Bull.R 1128, Forest Products Laboratory, Madison, Wisconsin (1929)

(30) Jeglum, D. H., Chem. Ind., 49, 440, 604, (1941)

(31) Vail, J. G., Ind. Engr. Chem., 27, 888 (1935)

(32) Perry, T. D., "Modern Wood Adhesives", p.33.

(32a) Brouse, Don, "Vegetable (Starch) Glue, Bull. R 30 , Forest Products Laboratory, Madison, Wisconsin (1938)

(33) Bear, R.S., and Samsa, E. G., Ind. Engr. Chem. 35, 721 (1943)

(34) Del Monte, John, "The Technology of Adhesives", p.134, Reinhold Publishing Corp., New York (1947)

(35) Kalle and Company, A. G., Brit. Pat. 488, 686, July 12, 1938, (Abstract oniy)

(36) Cogan, H., and Quarles, R. (to Carbide and Carbon Chemicals Corp) U. S. Patent 2,387,831. 
(37) Abrahm, H., "Asphalts and Allied Substances", p.324, D. Van Nostrand Co., New York, (1945)

(38) Wise, Louis E., "Wood Chemistry", p.774, Reinhold Publishing Corp., New York, (1944) 
Acknowledgment

This research was made possible through

a fellowship grant from the University of Loulgville Institute of Industrial Research as a portion of contracted research with the Stapling Machine Company 
VITA

Edwin Rimmer Arbegust, son of Harry Rimmer Arbegust and Josephine (Ulrich) Arbegust, was born May 20, 1923. He attended st. Benedict's Parochlal School and Graduated from St. Xavier High School, Loulaville, Ky ., In June, 1941. He attended Purdue University, Lafayette, Ind., september, 1941 and received a B. S. In Chemical Engineering June, 1944. He served in the Navy for three yearg; he received his commission as Ensign, U. S. N. R. from the U. S. N. R. M1dshipman School, New York, N. Y., and served aboard the heavy cruiser, the U.S.S. St. Paul, as an Engineering officer for eighteen months. Upon being discharged from the Navy, he resumed his education at the University of Loulsvilie, speed scientific school from which he obtained the Degree of Master of Chemical Engineering In June, 1947 . 